Ambiente \& Água - An Interdisciplinary Journal of Applied Science
ISSN 1980-993X - doi:10.4136/1980-993X
www.ambi-agua.net
E-mail: ambi.agua@gmail.com

\title{
Rapid assessment protocols of rivers as instruments of environmental education in elementary schools
}

\author{
doi:10.4136/ambi-agua.1996
}

Received: 02 Sep. 2016; Accepted: 26 Jun. 2017

\author{
Ariane Guimarães ${ }^{1}$; Aline Sueli de Lima Rodrigues²; \\ Guilherme Malafaia ${ }^{2 *}$ \\ ${ }^{1}$ Universidade Estadual de Goiás (UEG), Morrinhos, GO, Brasil \\ Programa de Pós-Graduação em Ambiente e Sociedade \\ ${ }^{2}$ Instituto Federal Goiano (IF Goiano), Urutaí, GO, Brasil \\ Departamento de Ciências Biológicas \\ *Corresponding author: e-mail: guilhermeifgoiano@gmail.com, \\ arianeifgoiano@gmail.com, alineifgoiano@gmail.com
}

\begin{abstract}
The aim of the present study is to assess the use of rapid assessment protocols (RAPs) of rivers as environmental education (EE) instruments in elementary schools. Therefore, EE activities were proposed to students from a Brazilian public elementary school. The activities included ranged from environmental-monitoring workshops to RAPs adapted to the level of schooling of the students. The students completed questionnaires before and after the activities in order to check their degree of knowledge prior to the activities and to assess the information acquired after participation in the activities. The results established that the RAP provided and/or helped to instill social values, knowledge, skills, actions, and competences linked to the environmental conservation of local rivers. The study therefore proves that the use of the RAP would be a valuable addition to EE projects and programs in elementary schools.
\end{abstract}

Keywords: environmental education, schools, students, rivers, water resources.

\section{Protocolos de avaliação rápida de rios como ferramenta de educação ambiental no ensino fundamental}

\section{RESUMO}

O presente trabalho teve por objetivo avaliar o uso de um protocolo de avaliação rápida de rios (PAR) como ferramenta de Educação Ambiental (EA) no nível fundamental da educação básica. Para isso, foram desenvolvidas atividades de EA envolvendo estudantes do ensino fundamental de uma escola pública (Ipameri, GO, Brasil). As atividades contemplaram desde oficinas de monitoramento ambiental até a aplicação do PAR adaptado ao nível de escolaridade dos estudantes. Os resultados apontam que o PAR utilizado foi capaz de propiciar ou contribuir com a construção de valores sociais, conhecimentos, habilidades, atitudes e competências voltadas para a conservação ambiental dos recursos fluviais locais. Conclui-se, portanto, que o PAR utilizado constituiu instrumento passível de ser utilizado em projetos e programas de EA em escolas de nível fundamental, considerando sua 
potencialidade em promover em jovens estudantes a observação, sensibilização e apropriação de conceitos referentes ao funcionamento dos rios e sua preservação/conservação.

Palavras-chave: educação ambiental, escolas, estudantes, recursos hídricos, rios.

\section{INTRODUCTION}

There is consensus that Environmental Education (EE) has enhanced awareness of environmental issues and has promoted conservationist practices (Fujitani et al., 2016; Marks et al., 2016). However, factors such as the expansion and changes in production processes, population growth, occupation of different ecological niches, uncontrolled migrations and urbanization have unbalanced the conditions of natural resources, including water sources (Oki and Kanae, 2006; Grimm et al., 2008).

According to Krupek (2010), the time taken to conduct EE does not keep pace with the rapid degradation of the environment. Careful evaluation of the impact of human activities on the functioning of aquatic ecosystems is essential; however, this task is difficult or even impossible when financial resources are scarce, when it must be performed in remote areas, and when it must be accomplished in a very short time span (Polonschii and Gheorghiu, 2017). However, this does not mean that the task should not be performed.

Concern over the rapid degradation of water resources therefore instills a sense of urgency to the need to develop rapid assessment protocols to measure environmental quality. Thus, the rapid assessment protocol (RAP) of rivers can be a complementary instrument to monitor water resources, because it assesses the parameters that determine the quality of rivers' physical conditions in an integrated way.

According to Rodrigues and Castro (2008), the RAP was created in the mid-1980s in the United States, when environment protection organizations realized that qualitative assessment methods should be set as an alternative to high-cost and time-consuming quantitative research. A document by Plafkin et al. (1989) was issued to set the first environment-monitoring protocols. It was a response to a report by the US Environmental Protection Agency "Surface Water Monitoring: A Framework for Change" (EPA 1987), which emphasized the need for reorganizing the monitoring programs in place. According to these authors, Plafkin's protocols aimed to provide basic data on aquatic life in order to assist in evaluating water quality and managing water resources.

From 1989 on, discussions about the relevance of using integrated criteria to evaluate the quality of water resources and of applying methods based on these criteria became more frequent. Currently, the RAP has been used in Canada, Germany, Australia and Great Britain. The Australian government, for example, developed a program called "Australian River Assessment System" (AusRivAS), which includes monitoring lotic ecosystems through the RAP, in order to evaluate the "health" of Australian river systems (Parsons et al., 2002). Therefore, RAP became a complementary way of assessing water quality through other mechanisms such as physicochemical and microbiological analyses applied to water and soil. However, care must be taken in interpreting the results, because the assessment collects information that enables planning the use and conservation of water resources (Rodrigues and Castro, 2008).

The RAP, by definition, is an instrument that gathers applicable methodological procedures focused on the rapid, qualitative and semi-quantitative assessment of a set of variables. These variables represent the main components and factors describing the conditions and control of ecological processes and river system functions (Callisto et al., 2002; Rodrigues and Castro, 2008). Natural conditions based on values recorded in minimally disturbed localities were used as "references" to develop the RAP (Plafkin et al., 1989). The 
starting premise assumes that the less the water courses are affected by man, the more favorable the environmental conditions will be (Minatti-Ferreira and Beaumord 2004). The evaluators must then determine the parameters to be assessed, the categories of environmental conditions to be checked, the localities to be evaluated and the scores related to each parameter. After receiving appropriate training, the evaluators go to the field and adjust the protocols to regional particularities with no need of technological apparatus. The scores attributed to each parameter indicate the "condition" of the system. Higher scores reflect a good conservation state, whereas lower scores evidence degradation. The sum of the scores attributed to each parameter provides to the final result, which will reflect the environmental integrity level of the basin section selected for study.

Several studies adopted the RAP as the instrument to assess the physical structure and functioning of river ecosystems (Rodrigues et al., 2008; Krupek, 2010; Lobo et al., 2011; Vargas and Ferreira-Júnior, 2012; Ferreira et al. 2016; Kieling-Rubio et al., 2015; Brito et al., 2016. ; Wahyudi et al., 2017, among others).

Adapting this instrument for its use in educational activities related to river preservation is a way to make it more useful, according to Bergmann and Pedrozo (2008). These authors formed groups of teachers, selected students to be monitors and developed activities such as lecturing, applying the RAP to set the basins' features, collecting river water for analysis, creating educational material and presenting their research in local and regional seminars. Students' participation in the activities suggested the importance of developing more dynamic EE activities to increase and systematize environmental knowledge. However, despite the success experienced by the aforementioned authors, only a small number of researchers concerned with environmental issues produce and analyze educational materials specifically for populations of a low-educational level, mainly for elementary school students (Bizzeril e Faria, 2003).

Accordingly, Guimarães et al. (2012) adapted the RAP to elementary school children from a small Brazilian city. Although their results were promising and highlighted the instrument's potential to be implemented in elementary schools for EE purposes, specific studies must still be developed to assess how this instrument, which is relatively new in Brazil, is capable of instilling social values, knowledge, skills and actions focused on environmental conservation.

Several studies in the literature show the difficulties and challenges of implementing EE programs in elementary schools (Cheng et al., 2013; Erdoğan, 2015; Genc, 2015; Hsueh and $\mathrm{Su}, 2016)$. These difficulties are generally related to teachers' lack of qualifications and abilities to develop EE activities, lack of significant budgetary resources for the development of EE projects/programs in schools, lack of EE-related teaching materials, lack of school community understanding and support to put in place actions to improve environmental quality, among others.

The RAP is an interesting alternative to be used in EE in elementary schools, since it requires neither high investments nor qualified personnel for its implementation. According to Rodrigues and Castro (2008), any previously trained person is able to use the RAP, since its use is simple. Thus, one can ask: can the RAP enhance or improve knowledge related to rivers or streams? Can the RAP instill social values focused on protecting water resources? Which actions or competencies aiming at preserving rivers are triggered or modified by RAP' activities? Can EE that utilizes the RAP change the perceptions of young students regarding rivers and their environmental conditions? Can the RAP increase these students' perceptions of factors having direct or indirect effects on rivers? This study therefore sought to answer these questions by assessing the RAP as an EE instrument for use in elementary schools in Mid-Western Brazilian counties. 


\section{MATERIALS AND METHODS}

\subsection{Rapid River Assessment Protocol}

The RAP version used in the present study was developed by Guimarães et al. (2012); it assesses eleven parameters, whose results highlight local conditions based on a scale that ranges from "great", to "good" and "bad" conditions. It was possible to assign scores concerning the conditions recorded in the study site based on the description of each parameter composing the RAP. The scores increased depending upon the quality of the habitat, which could change depending on the location at which the observations were done. The score of river-bank parameters should be assigned to each bank (left or right). Thus, the banks may present different environmental conditions and the assessment applied to each section is expressed by the arithmetic mean of the scores.

\subsection{Target audience and the dynamics of Environmental Education activities}

A total of 109 elementary school students $\left(6^{\text {th }}, 7^{\text {th }}\right.$, and $8^{\text {th }}$ grades $)$ from a Brazilian public school participated in a study called "Environmental Monitoring Workshop", which was carried out in two stages. First, a theoretical approach was adopted to introduce the students the aims and justifications of the study, to the importance of monitoring watercourses, to the definition and importance of environmental indicators, as well as to the presentation of each of the parameters assessed through the RAP. Subsequently, the students went to the field and applied RAP to a section of the Lavapés Stream (Ipameri, GO, Brazil). It is worth mentioning that all participants assessed the same stream section.

An investigative questionnaire was answered by the students before and after the RAP activity, in order to check whether the RAP activity provided or improved specific knowledge about rivers, fostered the emergence of socio-environmental values, or triggered actions or skills focused on river preservation. Specific groups were established in order to measure the influence of the RAP activity and of the environmental monitoring workshop on the present results.

i. Group $01(\mathrm{NW}+\mathrm{NR})$ : composed of 37 students from the $6^{\text {th }}$ and $7^{\text {th }}$ grades of an elementary school. Students in this group did not participate in the environmental monitoring workshop (NW) and were not able to work with the RAP (NR).

ii. Group $02(\mathrm{~W}+\mathrm{NR})$ : Composed of 42 students from the $7^{\text {th }}$ and $8^{\text {th }}$ grades of an elementary school. Students in this group participated in the environmental monitoring workshop (W), but were not able to work with the RAP (NR).

iii. Group $03(\mathrm{~W}+\mathrm{R})$ : Composed of 30 students from the $7^{\text {th }}$ and $8^{\text {th }}$ grades of an elementary school. Students in this group participated in the environmental monitoring workshop (W) and also went to the field to work with the RAP (R).

The activity involving the environmental monitoring workshop and RAP application in the field lasted approximately one month (August and September 2016). Students participating in the NW + NR group, although they did not participate in the workshop and RAP application, answered the questionnaire at the beginning and end of the study. This questionnaire evaluated students' knowledge about some concepts related to watercourses, and identified their actions, values and behaviors linked to certain situations concerning water pollution or the different environmental impacts on river ecosystems. 


\subsection{Data analysis}

Data were subjected to qualitative and quantitative analyses to compare the groups assessed herein; accordingly, descriptive statistics techniques were used. Categories found in Table 1 were adapted from Rodrigues and Malafaia (2009) and adopted to analyze students' conceptions regarding rivers.

Table 1. Representative categories of the herein adopted river concepts.

\begin{tabular}{|c|c|}
\hline Category & Description \\
\hline Romantic & $\begin{array}{l}\text { Concept of "super-nature", mother nature. It points towards the } \\
\text { grandiosity of rivers, which are always harmonious, exalted, } \\
\text { wonderful, balanced and of aesthetic beauty. Man is not involved in } \\
\text { the process. This concept relies on a dualistic view, man vs nature. }\end{array}$ \\
\hline Utilitarian & $\begin{array}{l}\text { Also dualistic, this concept interprets rivers as life-providers to man; } \\
\text { rivers are understood as a source of resources for man. The concept } \\
\text { relies on an anthropocentric sense. }\end{array}$ \\
\hline Broad/Broader & $\begin{array}{l}\text { Defines rivers in a broader and more complex way. Covers the } \\
\text { natural and resulting aspects of human activities. Results from the } \\
\text { interaction among biological, physical, economic and cultural } \\
\text { factors. }\end{array}$ \\
\hline $\begin{array}{l}\text { Reducing or } \\
\text { natural }\end{array}$ & $\begin{array}{l}\text { Views rivers from a strictly natural-physical perspective, without } \\
\text { regard for human interactions and production processes. Unlike the } \\
\text { "romantic" category, it does not exalts nature. }\end{array}$ \\
\hline $\begin{array}{l}\text { Socio- } \\
\text { environmental }\end{array}$ & $\begin{array}{l}\text { Relies on a historical-cultural perspective. Men and the landscape } \\
\text { are the constituent elements of rivers. Man takes ownership of rivers } \\
\text { to trigger historical processes. }\end{array}$ \\
\hline
\end{tabular}

\section{RESULTS AND DISCUSSION}

The first item in the questionnaire referred to the students' understanding about "what a river would be". Students in Group $1(\mathrm{NW}+\mathrm{NR})$ did not show divergent conceptions during the study, as expected. However, although these students did not participate in the environmental monitoring workshop, most of them showed "broad" conceptions about it, since they defined the rivers in a broader and more complex way (Figure 1A). This conception shows their understanding about the natural and human aspects resulting from the interaction among biological, physical, economic and cultural factors.

The present results may be explained by the fact that students were in constant contact with daily issues related to watercourses, such as garbage on the river banks, deforestation, discomfort due to bad odor, among others. According to Sulaiman (2011), even before the internet and globalization, the amount of information spread by the written press, radio and television had already exceeded the amount of information found in text books, so students already had knowledge related to watercourses. Similar results were recorded in Group 3 (W $+\mathrm{R}$ ), also because the students already had previous knowledge about the topics discussed during the environmental-monitoring workshop (Figure 1C). 
Students in Group $2(\mathrm{~W}+\mathrm{NR})$ had an "utilitarian" concept of what a river would be (39.5\%) before the workshop. However, they showed a broader concept about rivers after it; their scores increased from 44.2 to $53.5 \%$ (Figure 1B). These data provide evidence that the discussions about environmental concepts during the monitoring workshop were able to increase students' perceptions about rivers.
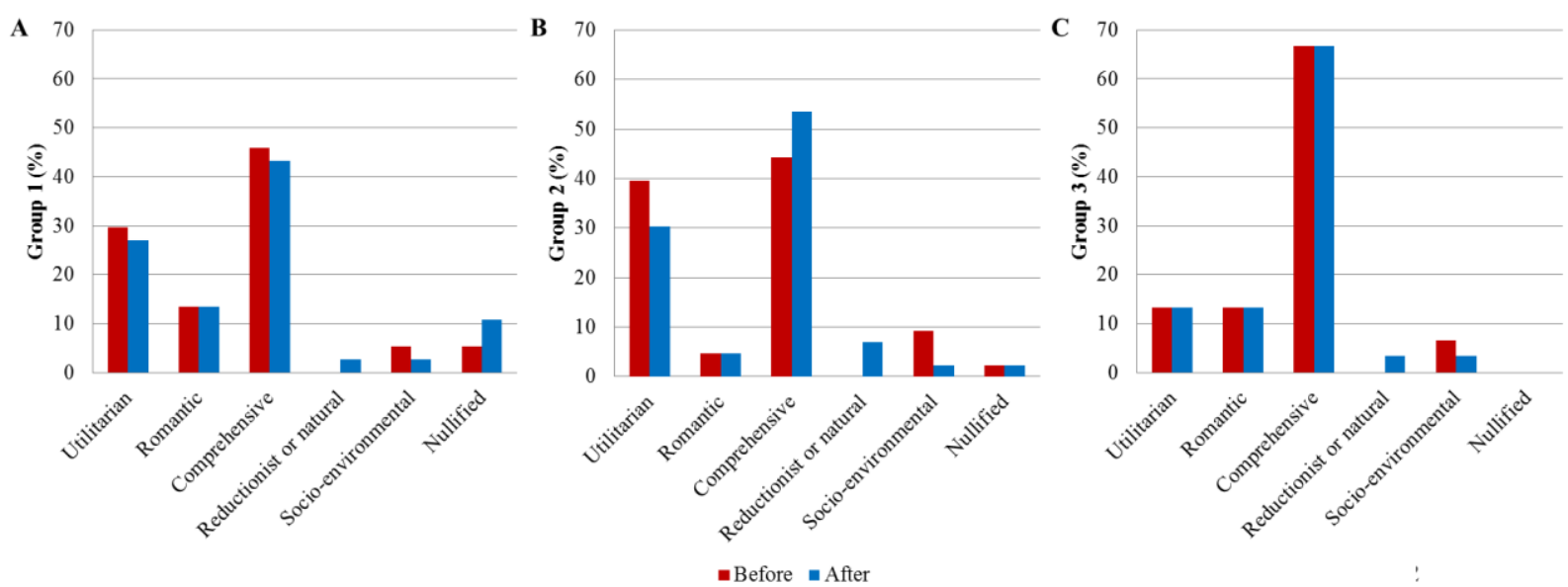

Figure 1. Concepts about what a river is - before and after the environmental education activity. Data collected from a public elementary school in Ipameri, GO, Brazil; A) Group 1 (NW + NR); B) Group $2(\mathrm{~W}+\mathrm{NR})$; C) Group $3(\mathrm{~W}+\mathrm{R})$.

The concept of students in Group $1(\mathrm{NW}+\mathrm{NR})$ about rivers' relevance (second item in the questionnaire) was also in the "broad" category, although they just had a moderate increase in their scores at the end of the study, from 54.1 to 59.5 (Figure 2A). This can be explained by the interest of students who did not participate in the activities possibly exchanging experiences with the students who participated in the workshop, or by the fact that the environmental issue is a cross-cutting theme that may have been addressed by other disciplines during the time the questionnaires were being used.
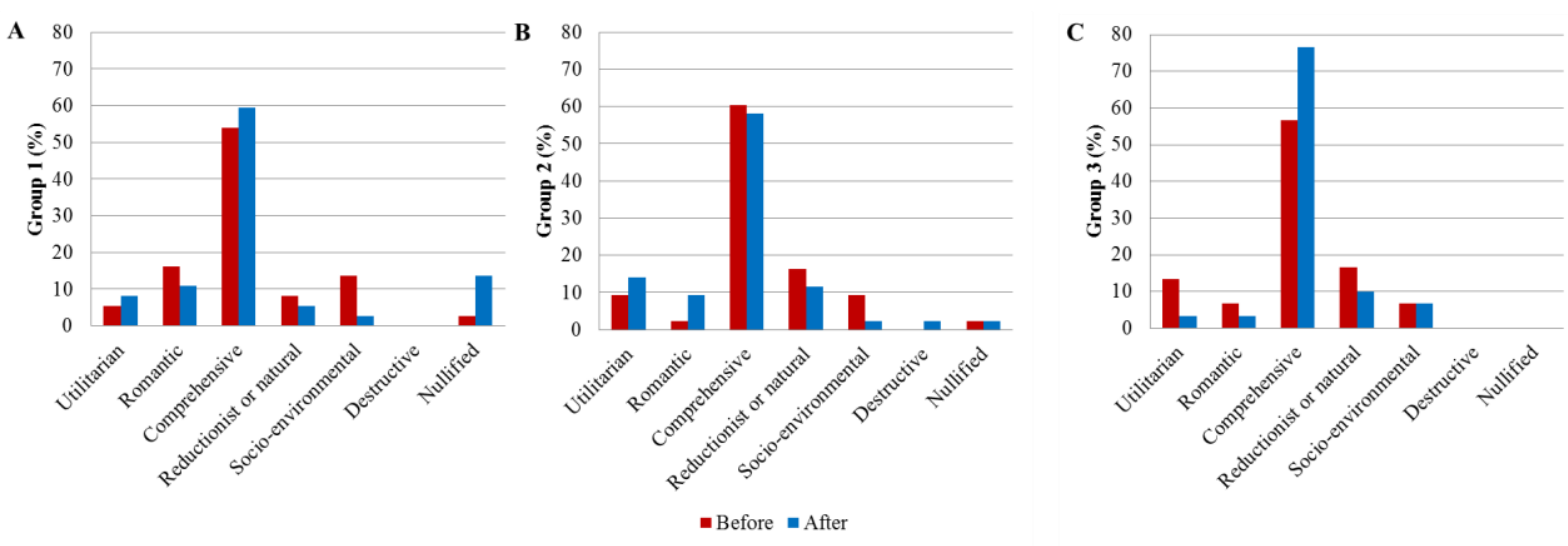

Figure 2. Concepts about the importance of rivers according to data collected from a public elementary school in Ipameri, GO, Brazil; A) Group $1(\mathrm{NW}+\mathrm{NR})$; B) Group $2(\mathrm{~W}+\mathrm{NR})$; C) Group $3(\mathrm{~W}+\mathrm{R})$. 
The different concepts shown by students in Group $3(\mathrm{O}+\mathrm{P})$ before and after RAP implementation and the monitoring workshop show the positive influence the activity had on students' knowledge and awareness. When the activity started, $56.7 \%$ of the students in this group had a "broader" view of rivers' relevance; at the end of it, $76.7 \%$ of them had achieved the same score (Figure 2C). Besides addressing environmental issues directly related to the preservation of water resources, the monitoring workshop explored concepts associated with ecology and with the functioning of aquatic ecosystems. It opened students' eyes to the importance of preserving the rivers, which did not occur with the students who did not attend the workshop. It is also possible that the "reductionist" concept, which relies on the idea that the environment is strictly related to natural/physical aspects and excludes humans and their production processes, as less of an influence on students after the activity.

Students in Group $3(\mathrm{~W}+\mathrm{R})$, however, showed broadened knowledge about the activities or actions, measures or behaviors that can be adopted to preserve rivers (third item in the questionnaire) after RAP application and the workshop (Figure 3C). The other groups presented increase in some items, but their increase was lower than that recorded in the $\mathrm{W}+\mathrm{R}$ group.

According to Curado and Angelini (2006), students tend to bring knowledge, concepts and assumptions about the topics addressed in any activity in which they participate, and this seed germinates throughout the learning journey. However, these authors acknowledge that the contact with nature through interpretive field trips outdoors, for instance, is recommended because it brings students closer to natural environments and encourages them to acquire a deeper understanding. Fagundes and Araújo (2011), state that using the outdoors for meaningful learning is a fundamental strategy, since it alters the students' behavior towards the environment they in which live.

Accordingly, it may be noted that the RAP is an instrument that takes students closer to nature and that helps to improve their knowledge about water courses; moreover, it can reinforce social values focused on preserving the environment. The results of the present study show that the RAP broadened students' perceptions about rivers and their environmental conditions, and helped to identify the activities, behaviors or actions that have direct or indirect impact on rivers.

Another aspect which reflected the students' change in perceptions regarding responsibility river preservation (fourth item in the questionnaire) was also observed throughout the current study. Students who participated in the workshop and in RAP application (Group 3: $\mathrm{W}+\mathrm{R}$ ) showed a broadened awareness about people's responsibility for river preservation, when their answers before and after the project were analyzed (Figure 4). Jacobi (2003) states that promoting environmental awareness is also a way to enable people's participation in decision-making processes, as well as to strengthen their coresponsibility for supervising and controlling the environmental degradation "agents".

Finally, students were asked about what should be done to promote the preservation of rivers (fifth item in the questionnaire). The results of Group $3(\mathrm{~W}+\mathrm{O})$ show that the activity (monitoring workshop associated with RAP application) influenced the students, because it improved their perceptions about actions that favor environmental preservation (Figure 5). Students who participated in all the activities (Group 3: $\mathrm{W}+\mathrm{R}$ ) realized that building or cultivating near river banks are practices that impair the preservation of watercourses. In addition, these students were able to understand the importance of participating in EE projects and of activities that maintain the quality of watercourses (their scores increased from 46.5 to $81.4 \%)$. 

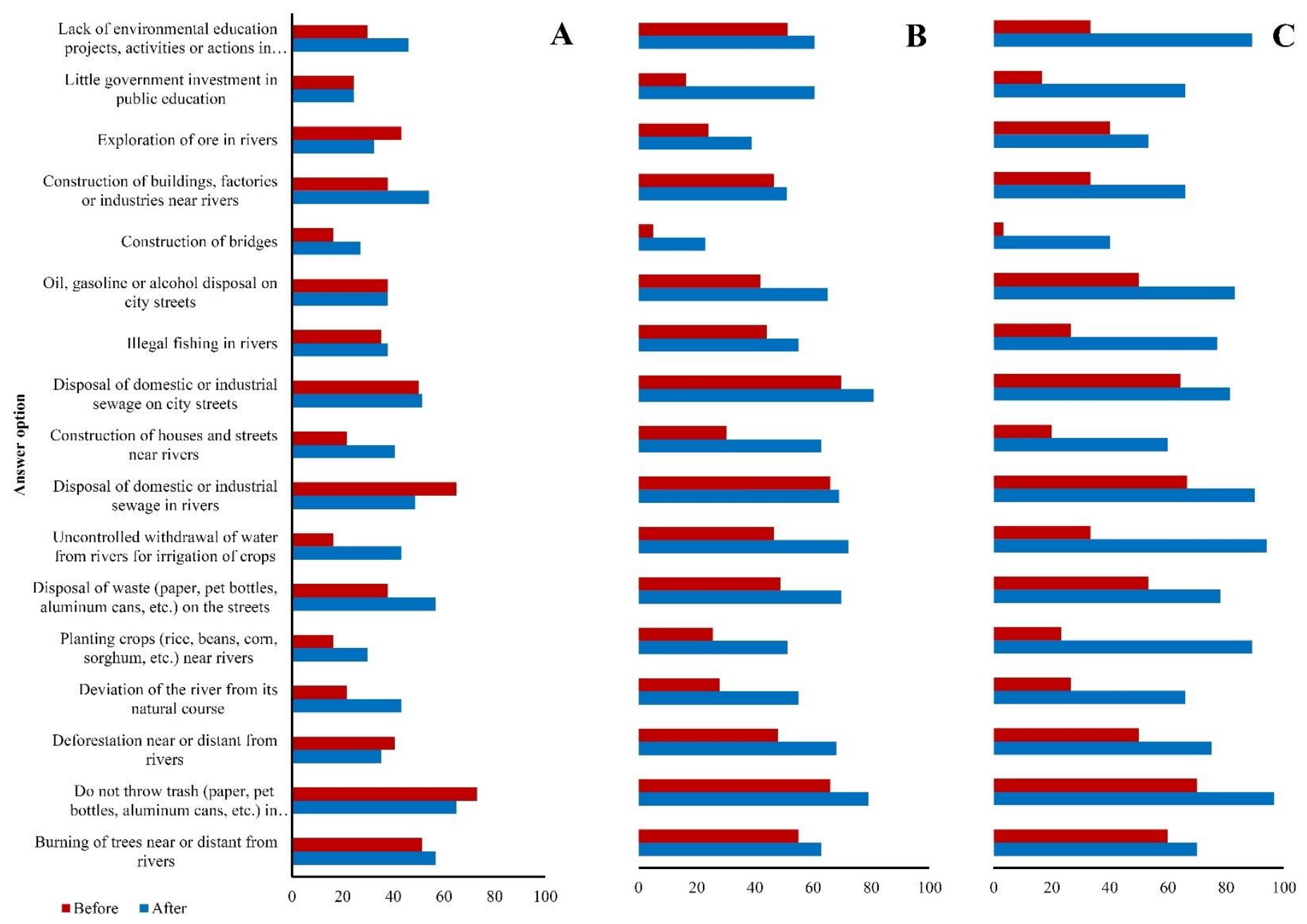

Percentage of students choosing the answer option (\%)

Figure 3. Activities, behaviors or actions identified by students in different research groups, before and after the environmental activity. A) Group $1(\mathrm{NW}+\mathrm{NR})$; B) Group $2(\mathrm{~W}+\mathrm{NR})$; C) Group $3(\mathrm{~W}+\mathrm{R})$. 


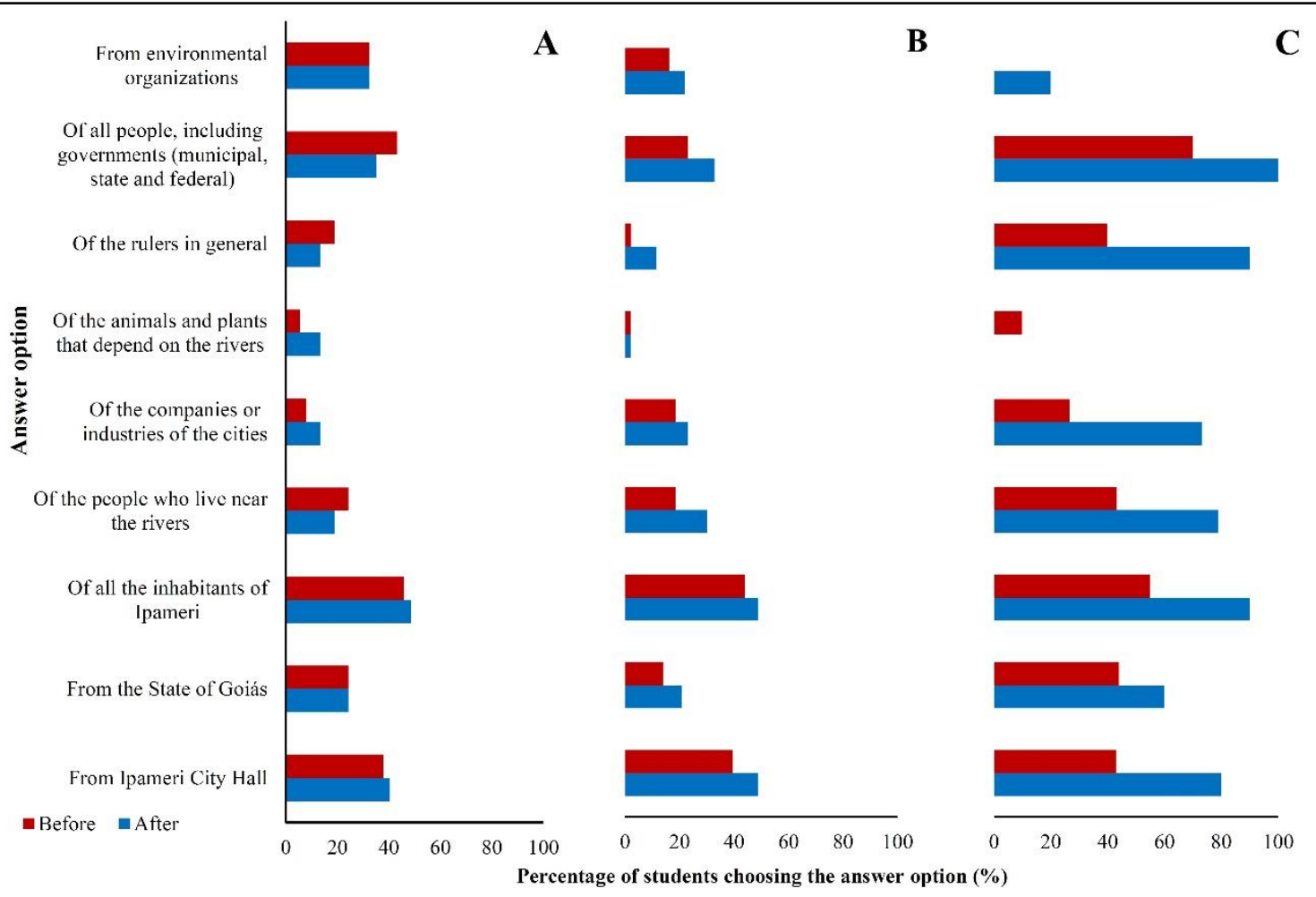

Figure 4. Responsibility for preserving and caring for rivers, the opinion of students from a public elementary school in Ipameri, GO; A) Group $1(\mathrm{NW}+\mathrm{NR})$; B) Group $2(\mathrm{~W}+\mathrm{NR})$; C) Group 3 (W + $\mathrm{R})$.

\section{FINAL CONSIDERATIONS}

The results of the present study highlight the fact that applying the RAP to EE projects implemented in educational institutions is a good alternative, since it calls children's attention to the environmental conditions of local water resources. Based on technical criteria described in the RAP, in a manner which elementary-school children could understand, students ended up understanding and identifying the possible impacts on rivers that may go unnoticed in their daily lives, mainly because these impacts have already been incorporated into the daily lives of the local citizenry, so that they are no longer seen as an environmental issue. Thus, activities like the ones conducted in the current study, along with theoretical and refective activities, are ways to encourage the development of an integrated understanding regarding rivers and water resources (including their ecological aspects). The strengthening of a critical view about environmental issues, as well as the encouragement of individual and collective participation in activities focused on the preservation of water resources, are ways to assure environmental quality through participative citizenship.

It is worth noting that, although the present study has presented interesting and promising results on RAP application in EE projects, it must be used in conjunction with lectures, workshops or other formal instruction in order to clarify and guide its use. The RAP version used in the present study can be incorporated into EE programs and/or projects in elementary schools, as well as in public or private institutions and in EE or environmental conservation projects linked to organizations related to environmental preservation. 

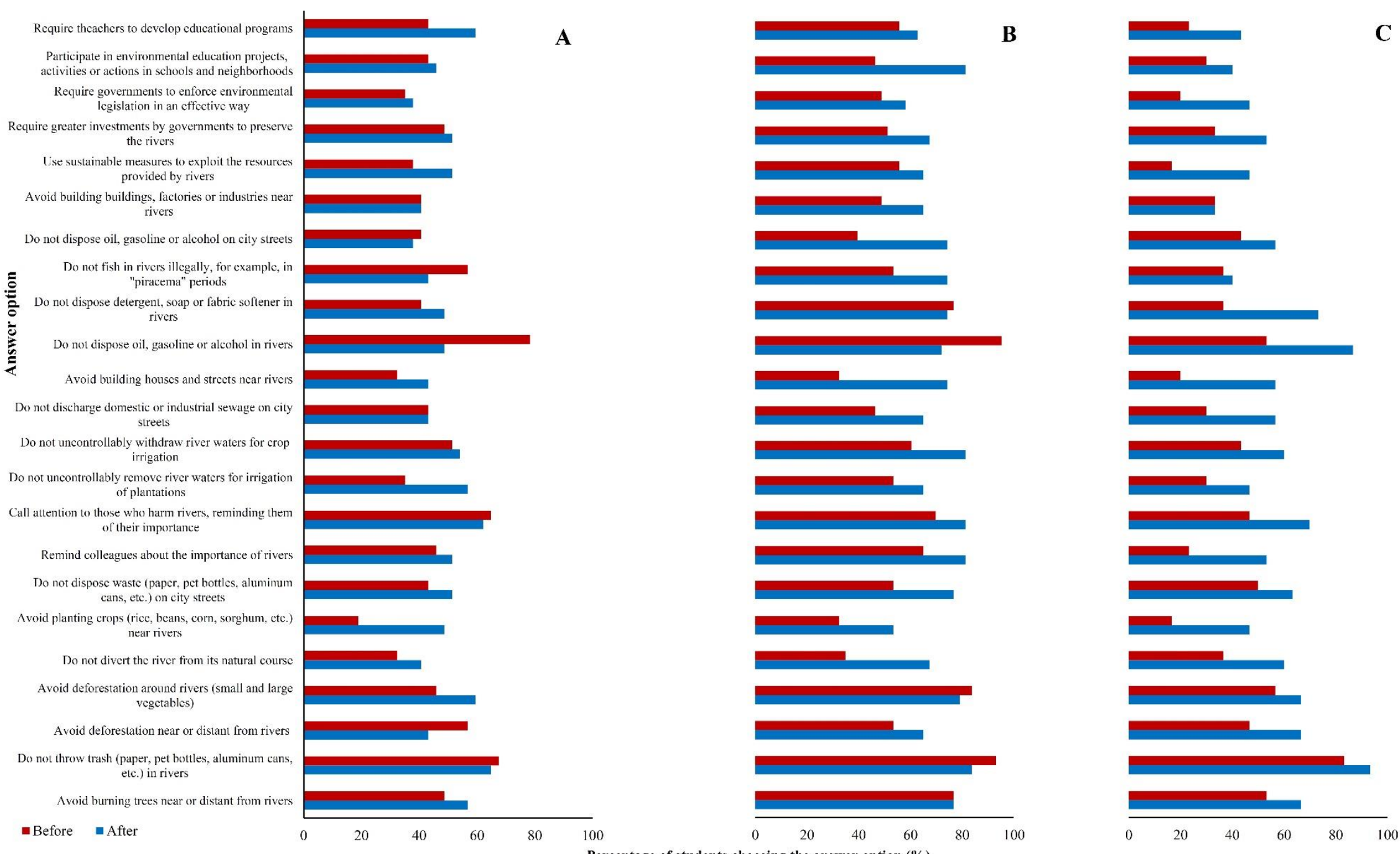

Figure 5. Opinion about what should be done to preserve and conserve rivers, opinion of students from a public elementary school in Ipameri, $\mathrm{GO}$; A) Group $1(\mathrm{NW}+\mathrm{NR})$; B) Group $2(\mathrm{~W}+\mathrm{NR})$; C) Group $3(\mathrm{~W}+\mathrm{R})$. 


\section{REFERENCES}

BERGMANN, M.; PEDROZO, C. S. Explorando a bacia hidrográfica na escola: Contribuições à educação ambiental. Ciência \& Educação, v. 14, n. 3, p. 537-53, 2008. http://dx.doi.org/10.1590/S1516-73132008000300011.

BIZZERIL, M. X. A.; FARIA, D. S. A Escola e a Conservação do Cerrado: uma análise do ensino fundamental do Distrito Federal. Revista Eletrônica do Mestrado em Educação Ambiental, v. 10, n. 1, p. 19-31, 2003.

BRITO, M. T. S.; NASCIMENTO-FILHO, S. L.; VIANA, G. F. S.; MELO-JÚNIOR, M. Aplicação de um protocolo de avaliação ambiental rápida em dois reservatórios do semiárido brasileiro. Brazilian Journal of Aquatic Science and Technology, v. 20, n. 1, p. 1-5, 2016. http://dx.doi.org/10.14210/bjast.v20n1.6992

CALliSTO, M.; FERREIRA W.; MORENO P.; GOULART M. D. C.; PETRUCIO M. Aplicação de um protocolo de avaliação rápida da diversidade de habitats em atividades de ensino e pesquisa (MG-RJ). Acta Limnologica Brasiliensia, v. 14, n. 1, p. 91-98, 2002 .

CURADO, P. M.; ANGELINI, R. Evaluation of environmental education activity in interpretive Trial three years after its accomplishment. Acta Scientiarum. Biological Sciences, v. 28, p. 395-401, 2006.

CHENG, Y. M.; LOU, S. J.; KUO, S. H.; and SHIH, R. C. Investigating elementary school students' technology acceptance by applying digital game-based learning to environmental education. Australasian Journal of Educational Technology, v. 29, n. 1, p. 96-110, 2013. https://doi.org/10.14742/ajet.65

ERDOĞAN, M. The effect of summer environmental education program (seep) on elementary school students' environmental literacy. International Journal of Environmental and Science Education, v. 10, n. 2, p. 165-181, 2015.

FAGUNDES, S. F.; ARAÚJO, L. E. B. Analisando a educação ambiental na Escola Municipal Anita Garibaldi: a influência de atividades práticas para a construção do conhecimento. Monografias Ambientais, v. 4, n. 4, p. 718-729, 2011. http://dx.doi.org/10.5902/ 223613083949

FERREIRA H. L. M.; CASTRO, P. T. A.; MELO, M. C.; CORDEIRO, P. F.; SOARES, A. C.; RIBEIRO, S. T. et al. Ecohydromorphology of river environments of the das Velhas River upstream of Rio de Pedras hydroelectric reservoir, MG, Brazil. Revista Eletrônica de Gestão e Tecnologias Ambientais, v. 4, n. 1, p. 41-49, 2016. http://dx.doi.org/10.9771/gesta.v4i1.14293

FUJITANI, M. L.; MCFALL, A.; RANDLER, C.; ARLINGHAUS, R. Efficacy of lecturebased environmental education for biodiversity conservation: a robust controlled field experiment with recreational anglers engaged in self-organized fish stocking. Journal of Applied Ecology, v. 53, n. 1, p. 25-33, 2016. https://doi.org/10.1111/13652664.12560

GENC, M. The project-based learning approach in environmental education. International Research in Geographical and Environmental Education, v. 24, n. 2, p. 105-117, 2015. http://dx.doi.org/10.1080/10382046.2014.993169 
GRIMM, N. B.; FAETH, S. H.; GOLUBIEWSKI, N. E.; REDMAN, C. L.; WU, J.; BAI, X. et al. Global change and the ecology of cities. Science, v. 319, n. 5864, p. 756-760, 2008. https://doi.org/10.1126/science.1150195

GUIMARÃES, A.; RODRIGUES, A. S. L.; MALAFAIA, G. Adequação de um protocolo de avaliação rápida de rios para ser usado por estudantes do ensino fundamental. Revista Ambiente \& Água, v. 7, n. 3, p. 241-260, 2012. http://dx.doi.org/10.4136/ambiagua.996

HSUEH, S. L.; SU, F. L. Critical factors that influence the success of cultivating seed teachers in environmental education. Eurasia Journal of Mathematics, Science and Technology Education, v. 12, n. 11, p. 2817-2833, 2016. https://doi.org/10.12973/eurasia. 2016.02306a

JACOBI, P. Educação ambiental, cidadania e sustentabilidade. Cadernos de Pesquisa, v. 118, n. 3, p. 189-205, 2003. http://dx.doi.org/10.1590/S0100-15742003000100008

KIELING-RUBIO, M. A.; BENVENUTI, T.; COSTA, G. M.; PETRY, C. T.; RODRIGUES, M. A. S.; SCHMITT, J. L. et al. Integrated Environmental Assessment of streams in the Sinos River basin in the state of Rio Grande do Sul, Brazil. Brazilian Journal of Biology, v. 75, n. 2, suppl., p. 105-113, 2015. http://dx.doi.org/10.1590/1519-6984.1013

KRUPEK, R. A. Análise comparativa entre duas bacias hidrográficas utilizando um protocolo de avaliação rápida da diversidade de habitats. Ambiência, v. 6, n. 1, p. 147-158, 2010.

LOBO, E. A.; VOOS, J. G.; FIEDLER-JÚNIOR, E. A. Utilização de um protocolo de avaliação rápida de impacto ambiental em sistemas lóticos do Sul do Brasil. Caderno de Pesquisa, v. 23, n. 1, p. 18-33, 2011. http://dx.doi.org/10.17058/cp.v23i1.4726

MARKS, M.; CHANDLER, L.; BALDWIN, C. Environmental art as an innovative medium for environmental education in Biosphere Reserves. Environmental Education Research, v. 1, n. 1, p. 1-5, 2016. http://dx.doi.org/10.1080/13504622.2016.1214864

MINATTI-FERREIRA, D. D.; BEAUMORD, A. C. Avaliação rápida de integridade ambiental das sub-bacias do rio Itajaí-Mirim no Município de Brusque, SC. Saúde \& Ambiente, v. 4, n. 2, p. 21-27, 2004.

OKI, T.; KANAE, S. Global hydrological cycles and world water resources. Science, v. 313, n. 5790, p. 1068-1072, 2006. https://doi.org/10.1126/science.1128845

PARSONS, M.; THOMSM, M.; NORRIS, R. Australian River Assessment System: AusRivAS Physical Assessment Protocol. Canberra: Commonwealth of Australia and University of Canberra, 2002.

PlAFKIN, J. L.; BARBOUR, M. T.; PORTER, K. D.; GROSS, S. K.; HUGHES, R. M. Rapid bioassessment protocols for use in streams and rivers: Benthic macroinvertebrates and fish. Washington: USEPA, 1989. $339 \mathrm{p}$.

POLONSCHII, C.; GHEORGHIU, E. A multitiered approach for monitoring water quality. Energy Procedia, v. 112, p. 510 - 518, 2017. https://doi.org/10.1016/j.egypro. 2017.03.1138

RODRIGUES, A. S. L.; CASTRO, P. T. A. Protocolos de avaliação rápida: instrumentos complementares no monitoramento dos recursos hídricos. Revista Brasileira de Recursos Hídricos, v. 13, n. 1, p. 161-170, 2008. https://doi.org/10.21168/ rbrh.v13n1.p161-170 
RODRIGUES, A. S. L.; MALAFAIA, G. O meio ambiente na visão de discentes do município de Ouro Preto-MG. Revista de Estudos Ambientais, v. 11, n. 2, p. 44-58, 2009.

RODRIGUES, A. S. L; MALAFAIA, G.; CASTRO, P. T. A. Avaliação ambiental de trechos de rios na região de Ouro Preto-MG através de um protocolo de avaliação rápida. Revista de Estudos Ambientais, v. 10, n. 1, p. 74-83, 2008.

SULAIMAN, S. N. Educação ambiental, sustentabilidade e ciência: o papel da mídia na difusão de conhecimentos científicos. Ciência \& Educação, v. 17, n. 3, p. 645-662, 2011. http://dx.doi.org/10.1590/S1516-73132011000300008

WAHYUDI, A. H.; SURIPIN S. River performance assessment model. Procedia Engeneering, v. 171, p. 1505-1513, 2017. https://doi.org/10.1016/j.proeng.2017.01.482

VARGAS, J. R. A.; FERREIRA-JÚNIOR, P. D. Aplicação de um protocolo de avaliação rápida na caracterização da qualidade ambiental de duas microbacias do rio Guandu, Afonso Cláudio, ES. Revista Brasileira de Recursos Hídricos, v. 17, n. 1, p. 161-168, 2012. https://doi.org/10.21168/rbrh.v17n1.p161-16 